\title{
Anisotropy of magnetic susceptibility analysis of the Cantera Ignimbrite, San Luis Potosi, México: flow source recognition
}

\author{
C. I. Caballero-Miranda ${ }^{1}$, J. R. Torres-Hernández ${ }^{2}$, and L. M. Alva-Valdivia ${ }^{1}$ \\ ${ }^{1}$ Laboratorio de Paleomagnetismo y Geofisica Nuclear, Instituto de Geofisica, UNAM, Ciudad Universitaria, 04510 México DF, Mexico \\ ${ }^{2}$ Instituto de Geología, Universidad Autónoma de San Luis Potosí, San Luis Potosí, Mexico
}

(Received November 23, 2007; Revised April 16, 2008; Accepted May 27, 2008; Online published January 23, 2009)

\begin{abstract}
Anisotropy of magnetic susceptibility (AMS) was selected as the key technique to find the source of the widespread Cantera Ignimbrite and to seek its possible relationship with the San Luis Potosí Caldera. Eighteen sites (372 specimens from 155 cores) from the Oligocene Cantera Ignimbrite were sampled. AMS was measured on a KLY2 Kappabridge. AMS data were processed with Anisoft 3 software using Jelinek statistics as well as 'SpheriStat' principal components and density distribution. Mean susceptibilities range from 290 to $5026 \times 10^{-6}$ SI (average $\left.=2526 \times 10^{-6} \mathrm{SI}\right)$. The anisotropy degree $\left(P_{\mathrm{j}}\right)$ ranges from 1.005 to 1.055 , with only one site displaying a value of $1.134\left(P_{\mathrm{j}}\right.$ average $\left.=1.031\right)$. AMS ellipsoid shapes are mostly oblate, with the $T$-factor ranging from 0.843 to $0.144(T$ average $=0.529)$, although one site is mainly prolate $(T=-0.005)$, and three additional sites have an important proportion of prolate specimens. Magnetic fabrics of most sites shows $k_{3}$ axes around nearly circular distributions and $k_{1}-k_{2}$ axes around elongated-girdle distributions defining sub-horizontal foliation planes; exceptions to this are related to sites with a significant percentage of prolate specimens. Flow directions inferred from AMS analysis indicate several ignimbrite sources located along selected NW-SE linear features (faults and fractures such as El Potosino Fault) as well as along the rim of the caldera structure. The geometry of volcanic outcrops, the NW-SE faulting-fracture system, as well as the AMS results suggest that this is a caldera structure resembling the trapdoor-type (Lipman, 1997).
\end{abstract}

Key words: Anisotropy of magnetic susceptibility (AMS), magnetic fabric, inference of flow source, Cantera Ignimbrite, San Luis Potosi Volcanic Field (SLPVF), Tertiary, Mexico.

\section{Introduction}

It is common to associate voluminous ignimbrites with calderic structures (ring fissure eruptions) although in some cases the sources may be related to straight linear fractures as proposed by Ekren and Byers (1976) for an ignimbrite from Nevada, Wright and Walker (1977) for the Acatlan Ignimbrite from Jalisco (Mexico), and Aguirre and Labarthe (2003) for ignimbrites from the Sierra Madre Occidental. Intense explosive volcanism may also occur in extensive volcanic fields without calderic structures (Ekren $e t$ al., 1983).

Several techniques have been developed as paleocurrent indicators in attempts to locate the source vent of ignimbrites, for example those based on facies distribution or measurable petrofabric elements - such as grain or crystallographic preferred orientations, fluidal textures (e.g. Elston and Smith, 1970; Rhodes and Smith, 1972; Suzuki and Ui, 1982), and those based on magnetic fabric (Ellwood, 1982; Knight et al., 1986; Hillhouse and Wells, 1991; Cagnoli and Tarling, 1996; Palmer and MacDonald, 1999; Alva-Valdivia et al., 2005). In all cases the results usually indicate that the local paleoslope and paleogeographic elements may influence the flow direction inferred with these techniques,

Copyright (c) The Society of Geomagnetism and Earth, Planetary and Space Sciences (SGEPSS); The Seismological Society of Japan; The Volcanological Society of Japan; The Geodetic Society of Japan; The Japanese Society for Planetary Sciences; TERRAPUB. making the identification of the source vent difficult.

The magnetic fabric of rocks is usually evaluated by AMS measurements, focusing on the distribution of the AMS principal axes: concentration of $k_{3}$ (minimum) axes means well defined magnetic foliation; and clustering of $k_{1}$ (maximum) axes means well defined magnetic lineation. In ignimbrite studies, foliation, lineation and imbrication of foliation have been found closely related with flow directions and local flow dynamics - e.g. laminar or turbulent flow-(Inconorato et al., 1983; Knight et al., 1986; MacDonald and Palmer, 1990; Hillhouse and Wells, 1991; Cagnoli and Tarling, 1996; Palmer and MacDonald, 1999; Ort et al., 1999, 2003; Alva-Valdivia et al., 2005).

Cantera Ignimbrite outcrops reveal two semicircular and concentric morphologic features cut out on one side by a complex fracture-normal faulting system. The aim of this study is to provide arguments to elucidate whether the Cantera Ignimbrite had one central source, a calderic linear ring fissure source or straight linear fissure source based on the AMS study and considering basic facies distribution and pre-existing topography.

\section{Setting and Geology}

The Cantera Ignimbrite is the most voluminous and widely outcropping volcanic unit of the San Luis Potosi Volcanic Field (SLPVF). This field, of Oligocene age, is located mostly in the southwest corner of the state of San Luis 


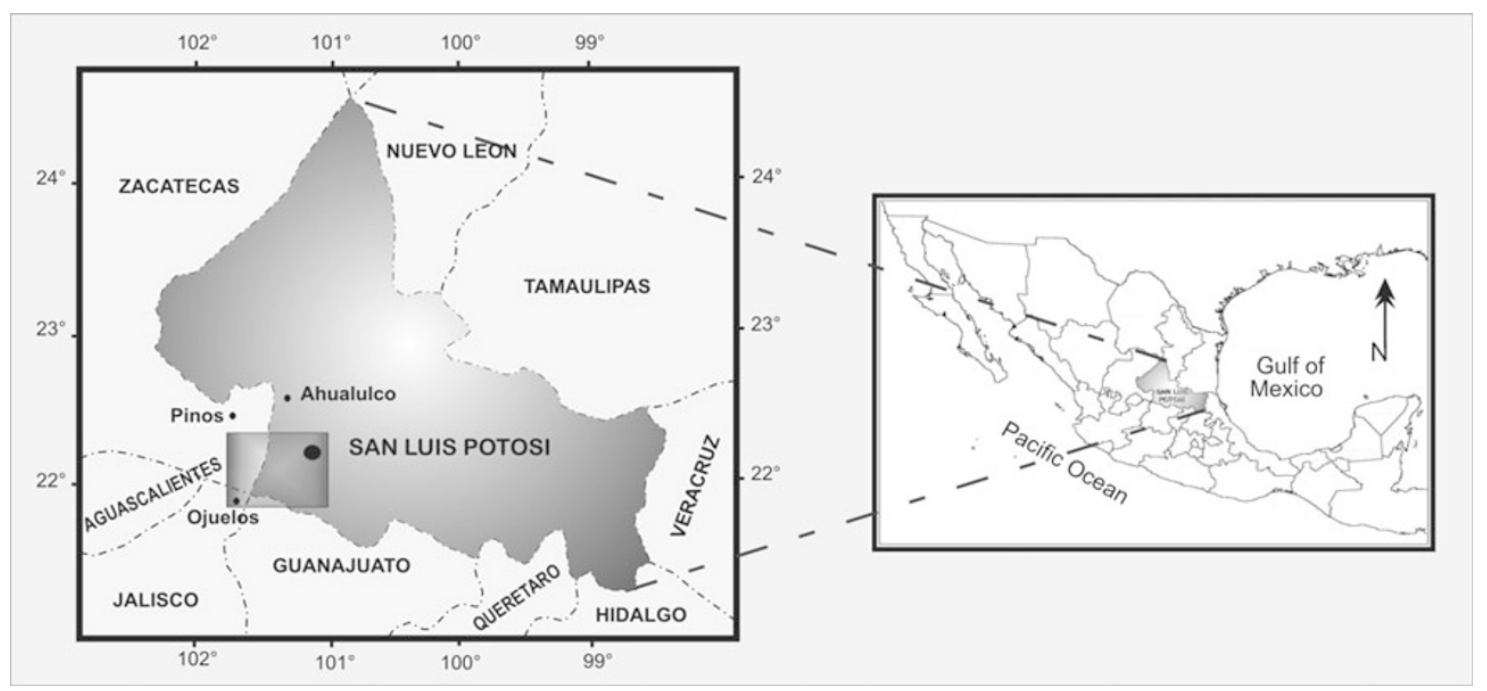

Fig. 1. Location of San Luis Potosi Volcanic Field (SLPVF) and studied area.

Potosi (Fig. 1) and overlies a Cretaceous basement (Fig. 2). The oldest volcanic rocks over this basement are andesites alternating with continental clastics (Labarthe et al., 1982). The units below the Cantera Ignimbrite (Portezuelo Latite and San Miguelito Rhyolite) show very prominent dome structures that constituted significant parts of the landscape during the emplacement of the Cantera Ignimbrite. There are several overlying ignimbritic and rhyolitic units (Fig. 2). The rhyolitic units are also characterized by some smaller domes (El Zapote Rhyolite). The entire ignimbrite-rhyolite sequence is affected by a NW-SE trend of fractures and normal faulting. Large graben structures of NE-SW trend (e.g. Valle de Reyes Graben) resulted in the uplift this region with respect to adjacent areas to the east.

The Cantera Ignimbrite has been important from a historical and economic point of view, since it has been used for construction of the most important colonial buildings of the city of San Luis Potosi. It has been studied and mapped (scales 1:50000 and 1:25000) by several authors (Labarthe and Tristán, 1978; Labarthe and Jiménez, 1993, 1994; Labarthe et al., 1995) and dated as 29 $\pm 1.5 \mathrm{Ma}$ (Labarthe et al., 1982). However, the source of the ignimbrite has not been precisely determined. Labarthe and Jiménez $(1992,1993)$ considered one source area along the NW-SE fracture lineaments, fractures that later controlled the normal faulting of the region. Furthermore, Aguirre and Labarthe (2003) recently proposed a fissure related origin for the Sierra Madre Occidental ignimbrites, including the SLPVF. On the other hand, the SLPVF shows two concentric semicircular morphologic features that suggest a particular caldera-like structure.

The caldera-like structure was detected by an external half ring of scarps and outcrops of the Cantera Ignimbrite and of the older San Miguelito Rhyolite. In this ring younger domes (Zapote Rhyolite) are also found. The internal half ring is quite evident by the semicircular lineation of several older domes (San Miguelito Rhyolite), dated as $29.2 \pm 0.8$ to $32.7 \pm 1.0 \mathrm{Ma}$ (Torres-Hernández, 2008). This structure is cut, at the northeastern portion, by an intense NW-SE complex fracture-normal faulting system (Fig. 3).

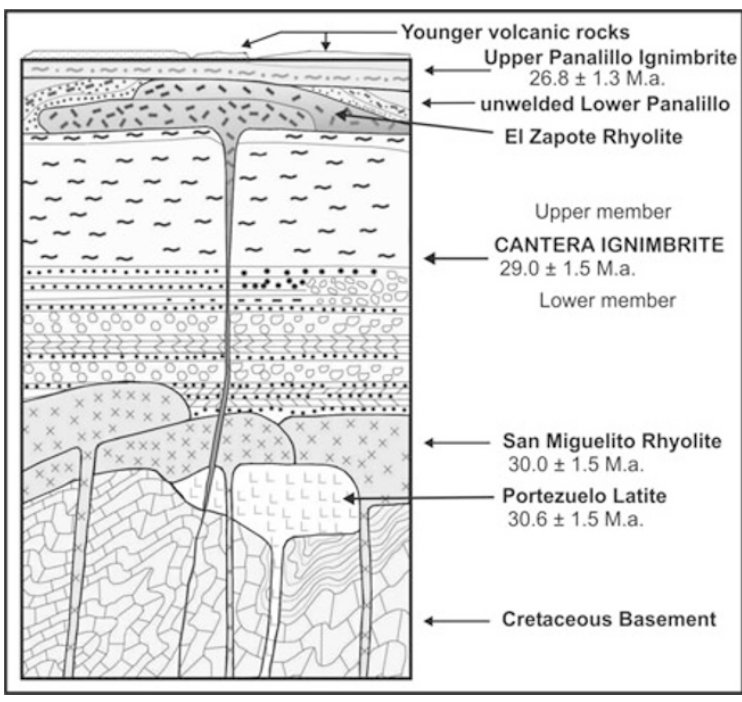

Fig. 2. Stratigraphic column with position and relative thickness of the Cantera Ignimbrite in relation to adjacent ignimbrite and rhyolitic units in the studied area. Thickness and folding of underlying basement is schematic.

Most of the normal faults of this system are downthrown to the SW, but one important inferred fault seems to be downthrown to the NE. The presence of Cretaceous basement to the SW of this fault (see outcrops north of the town of Calderon and around La Estrella in Fig. 3) and the absence of this basement to the NE, suggests that the time of this fault was different than the others, probably more recent.

The bedding and flow planes of the eastern Cantera Ignimbrite outcrops affected by the NW-SE faulting system generally dip slightly to the NE. In this area Labarthe and Jimenez (1992, 1993) suggest some relationship between the flow source and NW-SE lineaments. On the other side, bedding and flow planes from western Cantera Ignimbrite outcrops, which lie outside the caldera rim, generally show a slight dip to the $\mathrm{W}$ and $\mathrm{SW}$, without important fractures or faulting. 


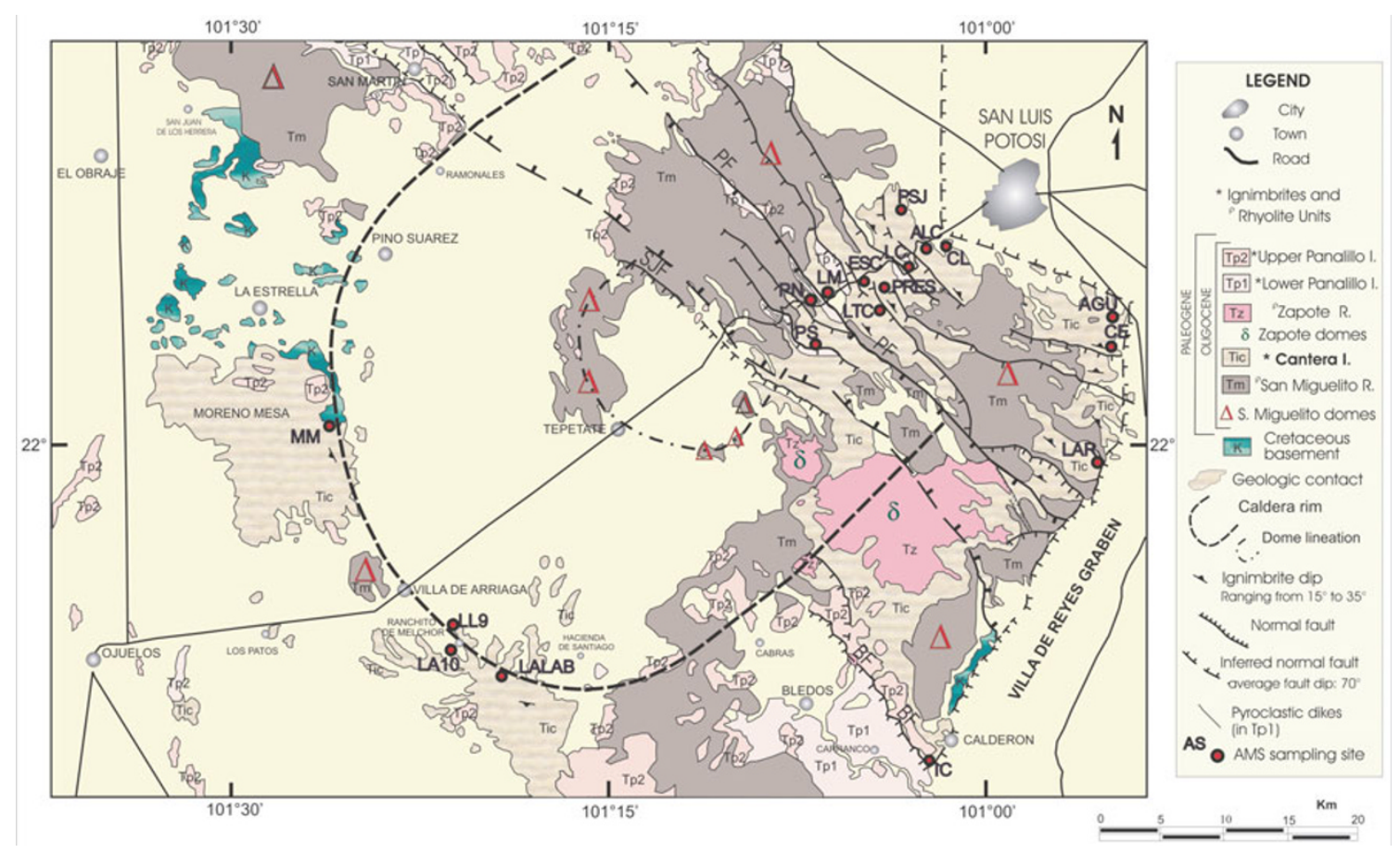

Fig. 3. Geologic map of SLPVF showing sampled sites and Cantera Ignimbrite outcropping, underlying and overlying volcanic units, the Cretaceous basement and structural features. Location of rhyolitic domes is also shown; those of older age were important paleogeographic features during Cantera Ignimbrite emplacement. PF $=$ Potosino fault, SJF $=$ San Jose Fault, BF = Bledos Fault.

\section{Cantera Ignimbrite Description}

The Cantera Ignimbrite is constituted by two members: a lower non-welded one, grayish white to pink, rich in ash (35-40\%) and white pumice (15-20\%), with accidental lithics of rhyolite and sandstone, and relatively few phenocrystals (5-15\%), and an upper highly welded member, pink to light brown and with a relative high content in phenocrystals (20-30\%). The members are easily identified by their morphology; the lower one is constituted by rounded hill landforms and the upper one by steep slope landforms with columnar structures and better developed bedding and flow planes than in the lower member. Sampling was performed at different levels from the upper member since it is harder and then easier for sampling and has fewer lithics.

Three kinds of facies have been recognized (TorresHernández, 2008): proximal (facies I), intermediate (II) and distal (III). The proximal facies are characterized by coignimbrite breccias, massive structures and poorly defined bedding or flow planes. The intermediate facies present well defined bedding and flow planes and the typical presence of small size accidental lithics $(<2 \mathrm{~cm})$, usually along preferred horizons. Distal facies also show well defined bedding and flow planes, but they do not contain accidental lithics. They present characteristic lenses of pumice fragments and some surge deposits.

In the NE outcrops, the facies from sites near the Potosino Fault and the nearest fault to the north are mainly proximal; meanwhile, in the remaining areas, facies are mostly intermediate. In the western outcrops in the zones nearest to the caldera rim, massive structures from proximalintermediate facies are dominant; three sites are outflow ignimbrites and one (LL9), is inflow. They can be observed to the south of Villa de Arriaga and on the eastern side of
Mesa Moreno. In summary, half of all sampled sites are from intermediate facies, around $25 \%$ are from proximalintermediate facies and the other $25 \%$ of the sites are from distal or intermediate-distal facies (relation of sites and facies are in Table 2).

Petrographic studies indicate that in the upper member crystal abundance is: sanidine $>$ quartz $>$ biotite $>$ plagioclase (oligoclase), and in the lower member the relative abundance is quartz $>$ sanidine $>$ plagioclase $>$ biotite. Plagioclase and biotite are in relatively higher proportions in the upper member. The matrix is partially devitrified in the lower member to highly devitrified in the upper member.

Opaque mineralogy studies identified hornblende, magnetite, titanomagnetite, pseudobrookite and rutile, as well as hematite, titanohematite, ilmenite, maghemite and goethite. Pseudobrookite, hematite and titanomagnetite crystals are the most common opaque minerals observed. Hornblende crystals show alteration rings to rutile and bands of pseudobrookite. In other cases hornblende shows alteration to titanohematite, which is particularly important in the case of the IC site. Pseudobrookite crystals show lamellar texture and sometimes lamellar intergrowths with rutile surrounded by goethite. Hematite crystals show anhedral forms and are irregularly altered to ilmenite. Sub-rounded and homogeneous-sized ilmenite crystals $(55-90 \mu \mathrm{m})$ are sometimes altered to pseudobrookite (Fig. 4).

Magnetic experiments of the whole Cantera Ignimbrite sequence have been performed and will be fully reported elsewhere (Alva-Valdivia, personal com.). They include Curie temperature estimations, isothermal remanence measurements, and hysteresis loop analyses. Preliminary results indicate pseudosingle domain (PSD) grains with 


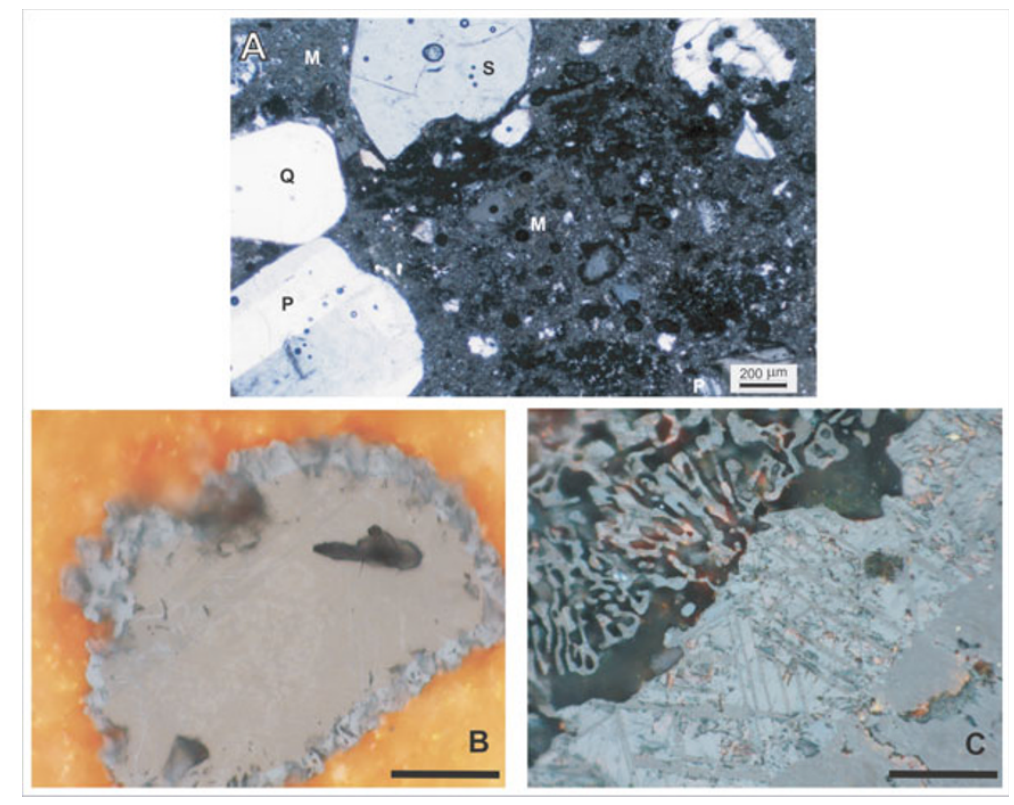

Fig. 4. Transmitted (A) and reflected (B and C) light microphotographs. (A) This photograph of PS site shows the fragmentary character of the phenocrystals: quartz (Q), sanidine (S) and plagioclase (P), englobed in a partially devitrified matrix (M). Bar in lower right corner is $200 \mu \mathrm{m}$. (B) The photograph shows a subrounded ilmenite crystal from CL site, partially altered to pseudobrookite and surrounded by rutile. (C) A partial view of a tabular crystal of pseudobrookite from LALAB site that is substituted by rutile along lamellar planes; toward the upper left corner of the photographs (border of the crystal), this substitution acquires a skeletal structure. Bars in lower right corner of B and C are $20 \mu \mathrm{m}$.

low coercivity and the influence in some cases of superparamagnetic grains. Curie temperatures are usually between $570^{\circ}$ to $610^{\circ} \mathrm{C}$, showing usually only one reversible phase. In some cases two phases can be detected, the lower one indicating a Curie temperature of maghemite of around $360^{\circ} \mathrm{C}$. Curie temperature experiments reveal that after heating, higher susceptibility values are characteristics in several samples, suggesting the formation of new phases. The results of these experiments are consistent with the mineralogy of opaque minerals reported above, since they suggest magnetite and titanomagnetite and, in addition, maghemite-titanomaghemite that was not identified by microscopic means.

\section{Sampling and Laboratory Procedures}

One-hundred and fifty five core samples were drilled with a gasoline-powered tool from 18 sites in the Cantera Ignimbrite distributed all around the SLPVF (Fig. 3). Sites were selected according with their accessibility for drilling, choosing areas with more matrix than lithics and by looking for the least chemical alteration in order to obtain a better defined magnetic fabric related with the flow process. Other criteria for selecting sampling sites were choosing them from areas affected by the NW-SE faulting system and also from places considered to be around the caldera rim. One of last sites (LL9), that was clearly identified as an inflow ignimbrite was particularly selected in order to observe its magnetic fabric in comparison with the others sites. At each site 7 to 10 cores were drilled depending on outcrop conditions, and oriented with a magnetic compass. Most cores were 10-12 cm long and in the laboratory 2 to 3 specimens were cut from each core, giving a total of 372 cylinder specimens $(2.5 \mathrm{~cm}$ diameter and $2.2 \mathrm{~cm}$ high $)$. Bedding or flow plane data were measured as well at each site with a magnetic compass for later structural corrections.

AMS was measured using a KLY-2 bridge (AGICO, Brno). Results were processed with Anisoft 3 software using Jelinek statistics (Jelinek, 1978), and performing structural correction. SpheriStat software was used for applying Gaussian counting point density distribution statistics ( $E=3 *$ Sigma; Robin and Jowett, 1986) and to facilitate plotting all the AMS data in high quality stereodiagrams: the susceptibility axes and their means, point density distribution curves, bedding and magnetic foliation planes (Fig. 5). Additionally, the SpheriStat principal component statistic was performed. This is not shown in the tables since it considers values of each main axis independently, which is not suitable for the AMS analysis but, in spite of this, it permits us to check alternate statistic parameters. Two sets of AMS data were analyzed to determine the ignimbrite flow source: (a) only geographical corrected data (not shown) and (b) structural corrected data. The structural correction was made based on bedding and flow planes clearly observed in the field. A comparative analysis of inferred flow from the two sets of data was performed in order to confirm field observations that indicate that the Cantera Ignimbrite emplacement pre-dates the NW-SE trend faulting.

\section{Anisotropy of Magnetic Susceptibility Results}

For a better analysis of the AMS data, sites were divided into three groups according to their geographical and structural location. (a) Northern Group: 10 sites affected by the intense NW-SE faulting system. Although some sites of this group seem to be inside the caldera-like structure, for others their position in relation to the caldera is not clear because of the faulting of the northern border of the caldera. (b) Eastern Group: 4 sites clearly located outside of the 


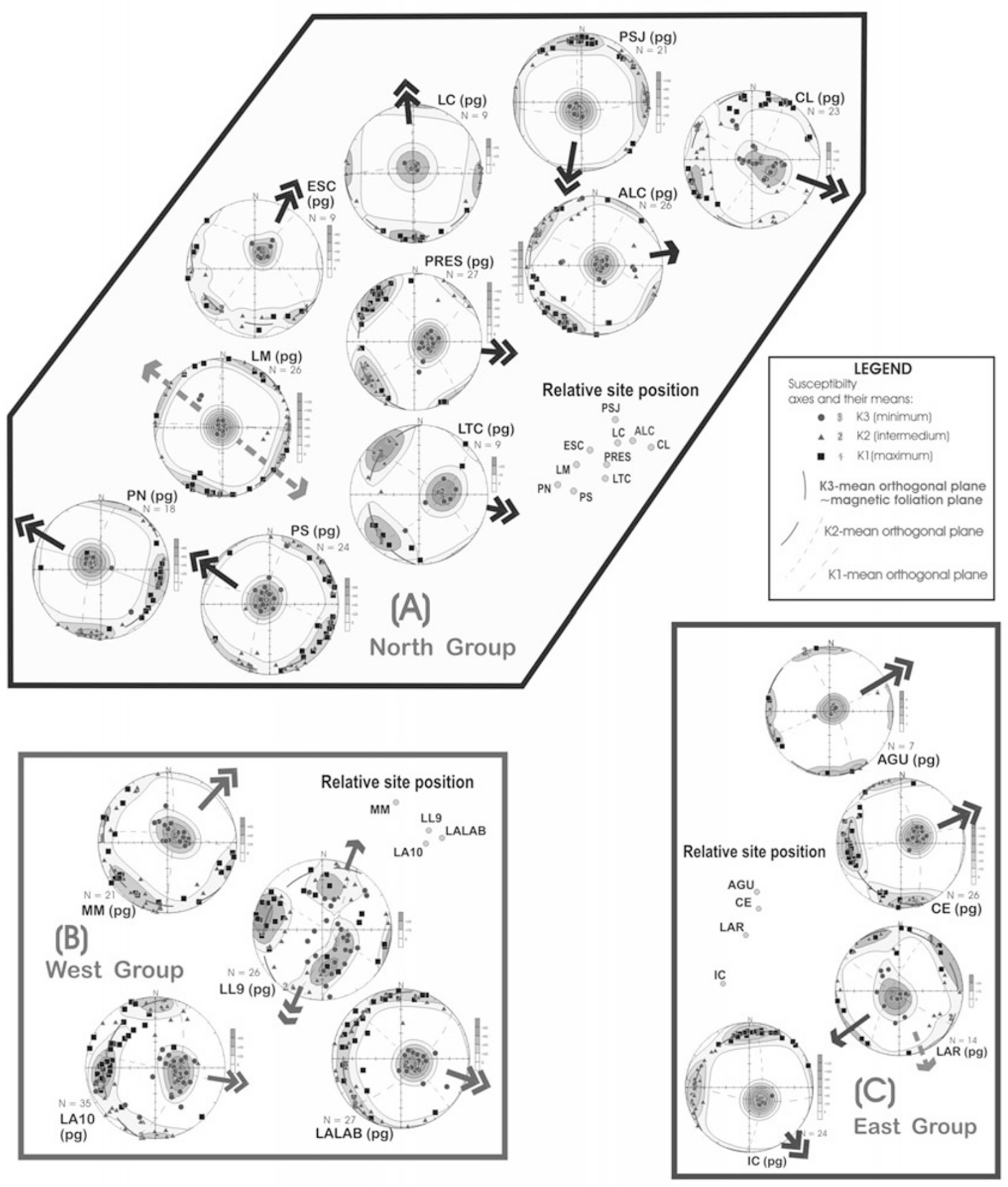

Fig. 5. AMS structural corrected data and point density distribution circles plotted on equal-area projections-of lower hemisphere- Inferred flow directions based on these data are also shown. (A) Sites from North group. (B) Sites from West group. (C) Sites from East group.

eastern part of the caldera-like structure, and very near to a NNE-SSW normal fault system which forms the western wall of the Villa de Reyes Graben. (c) Western Group: 4 sites around the S-SW border-scarp of the caldera structure, 3 outside of and 1 inside the caldera.

\subsection{Susceptibility and AMS parameters}

The susceptibility and AMS parameters employed here are those of Jelinek (1981): $T$ for shape and $P_{\mathrm{j}}$ for anisotropy degree. In Table 1 the averages of these parameters per site are shown, as well as the percentage of prolate specimens at each site. Mean susceptibility of all sites is $2522 \times 10^{-6} \mathrm{SI}$, ranging from 290 to $5026 \times 10^{-6} \mathrm{SI}$. The anisotropy degree $\left(P_{\mathrm{j}}\right)$ average of all sites is 1.032 , and ranges from 1.005 to 1.055 (only one site, IC, has higher $\left.P_{\mathrm{j}}=1.134\right)$. There are no particular relationships between mean susceptibility and anisotropy degree or with their geographical/geological location. The anisotropy shape is predominantly oblate and the $T$-factor average is 0.529 , ranging from 0.843 to 0.144 ; in most cases there are no or very few prolate specimens per site. Contrastingly, there are a few sites with predominance of or an important contribution of prolate anisotropy shapes: half of the specimens at one site are prolate (LL9, $T$ average $=-0.005$ ) and another three sites have a significant proportion of prolate specimens $(21 \%$ to $36 \%)$. For these sites a separated $T$ average of oblate and prolate specimens is presented in Table 1. 
Table 1. Susceptibility and AMS parameter averages per site $\left(n=\right.$ specimen number). Mean susceptibility is in SI units. $P_{\mathrm{j}}$ is Jelinek's anisotropy degree and $T$ is Jelinek's shape factor (ranging from +1 to -1 , positive are oblates, negative are prolates). Where percentage of prolate specimens is higher than $21 \%$ positive and negative $T$ values are averaged separately.

\begin{tabular}{|c|c|c|c|c|c|c|c|c|}
\hline & \multirow[b]{3}{*}{ Site } & \multirow[b]{3}{*}{$\mathrm{n}$} & \multirow{2}{*}{\multicolumn{3}{|c|}{ AMS parameters }} & \multirow{3}{*}{$\begin{array}{l}\% \text { of } \\
\text { prolate } \\
\text { spec. }\end{array}$} & \multirow{3}{*}{$\begin{array}{c}T \text { of oblate } \\
\text { specimens } \\
T>0\end{array}$} & \multirow{3}{*}{$\begin{array}{c}T \text { of prolate } \\
\text { specimens } \\
\mathrm{T}<0\end{array}$} \\
\hline & & & & & & & & \\
\hline & & & $\begin{array}{c}\text { Mean Sus } \\
\times 10^{-6}\end{array}$ & $\mathrm{Pj}$ & $T$ & & & \\
\hline \multirow{11}{*}{$\begin{array}{l}\text { 을 } \\
\text { 인 } \\
\text { 는 } \\
\text { 눈 }\end{array}$} & PSJ & 21 & 2421 & 1.021 & 0.664 & $5 \%$ & & \\
\hline & LC & 9 & 4529 & 1.019 & 0.738 & $0 \%$ & & \\
\hline & $\mathrm{CL}$ & 23 & 3405 & 1.036 & 0.843 & $0 \%$ & & \\
\hline & ESC & 9 & 1547 & 1.013 & 0.551 & $11 \%$ & & \\
\hline & ALC & 26 & 3454 & 1.018 & 0.644 & $4 \%$ & & \\
\hline & PRES & 27 & 4837 & 1.011 & 0.437 & $4 \%$ & & \\
\hline & LM & 26 & 1676 & 1.027 & 0.751 & $0 \%$ & & \\
\hline & LTC & 9 & 1406 & 1.055 & 0.534 & $0 \%$ & & \\
\hline & PN & 18 & 3408 & 1.024 & 0.561 & $6 \%$ & & \\
\hline & PS & 24 & 388 & 1.020 & 0.409 & $21 \%$ & 0.619 & -0.389 \\
\hline & Gp. average & 192 & 2707 & 1.024 & 0.613 & $5 \%$ & & \\
\hline \multirow{5}{*}{ 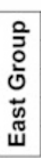 } & AGU & 7 & 2222 & 1.038 & 0.426 & $14 \%$ & & \\
\hline & $\mathrm{CE}$ & 26 & 901 & 1.032 & 0.593 & $4 \%$ & & \\
\hline & LAR & 14 & 5026 & 1.032 & 0.256 & $36 \%$ & 0.746 & -0.628 \\
\hline & IC & 24 & 914 & 1.134 & 0.749 & $0 \%$ & & \\
\hline & Gp. average & 71 & 2266 & 1.059 & 0.506 & $10 \%$ & & \\
\hline \multirow{5}{*}{ 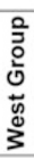 } & MM & 21 & 4513 & 1.041 & 0.738 & $5 \%$ & & \\
\hline & LL9 & 26 & 1714 & 1.005 & -0.005 & $50 \%$ & 0.298 & -0.309 \\
\hline & LA10 & 35 & 290 & 1.019 & 0.144 & $34 \%$ & 0.377 & -0.302 \\
\hline & LALAB & 27 & 2820 & 1.005 & 0.426 & $4 \%$ & & \\
\hline & Gp. average & 109 & 2334 & 1.017 & 0.326 & $25 \%$ & & \\
\hline & $\begin{array}{c}\text { general } \\
\text { average }\end{array}$ & 372 & 2522 & 1.032 & 0.529 & $12 \%$ & & \\
\hline
\end{tabular}

Table 2. Statistical analysis of structural corrected AMS directions ( $n=$ number of specimens per site). Short and long name of sites is described as well as bedding plane and facies ( $\mathrm{I}=$ proximal, II $=$ intermediate and III $=$ distal). In each site 2 statistics (Stat column) are shown, $J$ : Jelinek's statistic (Jelinek, 1978); $D$ : Gaussian counting ( $E=3 *$ Sigma) point density distribution (Robin and Jowett, 1986). $k_{1}$ is maximum AMS axis and $k_{3}$ is the minimum. $\alpha$ is confidence ellipse: minimum and maximum axes (see text for further explanation). Directions of $k_{3}$ that are not in bold are those with more elliptical than circular distribution.

\begin{tabular}{|c|c|c|c|c|c|c|c|c|c|c|}
\hline \multirow{3}{*}{ Group } & \multirow{3}{*}{ Site } & \multirow{3}{*}{$\begin{array}{l}\text { Bedding / } \\
\text { facies }\end{array}$} & \multirow{3}{*}{$\mathbf{n}$} & \multicolumn{7}{|c|}{ Statistical Analysis of AMS Principal Directions } \\
\hline & & & & \multirow{2}{*}{ Stat } & \multicolumn{2}{|c|}{ k1 } & \multirow{2}{*}{$\begin{array}{c}\alpha \\
\min / \max \end{array}$} & \multicolumn{2}{|c|}{ k3 } & \multirow{2}{*}{$\begin{array}{c}\alpha \\
\min / \max \end{array}$} \\
\hline & & & & & Dec & Inc & & Dec & Inc & \\
\hline \multirow{10}{*}{$\begin{array}{l}\text { 을 } \\
\text { 인 } \\
0 \\
\text { 壳 } \\
\text { z }\end{array}$} & $\begin{array}{c}\text { PSJ } \\
\text { Presa Sn Jose }\end{array}$ & $\begin{array}{c}\text { Bd: } 35 ; 18 / \\
\text { f. III }\end{array}$ & 21 & $\begin{array}{l}J \\
\text { D }\end{array}$ & $\begin{array}{l}358 \\
357\end{array}$ & $\begin{array}{l}10 \\
10\end{array}$ & $8 / 17$ & $\begin{array}{l}203 \\
207\end{array}$ & $\begin{array}{l}79 \\
77\end{array}$ & $3 / 5$ \\
\hline & $\begin{array}{c}\text { LC } \\
\text { La curva }\end{array}$ & $\begin{array}{c}\text { Bd: } 325 ; 15 / \\
\text { f. II }\end{array}$ & 9 & $\begin{array}{l}J \\
D\end{array}$ & $\begin{array}{l}181 \\
180\end{array}$ & $\begin{array}{l}8 \\
8\end{array}$ & $3 / 13$ & $\begin{array}{l}357 \\
355\end{array}$ & $\begin{array}{l}82 \\
82\end{array}$ & $3 / 4$ \\
\hline & $\begin{array}{c}\text { CL } \\
\text { Canada lobos }\end{array}$ & $\begin{array}{l}\text { Bd: } 335: 30 / \\
\text { f. III }\end{array}$ & 23 & $\begin{array}{l}\text { J } \\
\text { D }\end{array}$ & $\begin{array}{c}215 \\
32\end{array}$ & $\begin{array}{l}6 \\
4\end{array}$ & $12 / 36$ & $\begin{array}{l}100 \\
110\end{array}$ & $\begin{array}{l}77 \\
75\end{array}$ & $12 / 26$ \\
\hline & $\begin{array}{c}\text { ESC } \\
\text { Escalerillas }\end{array}$ & $\begin{array}{c}\text { Bd: } 317: 25 / \\
\text { f. II }\end{array}$ & 9 & $\begin{array}{l}J \\
\text { D }\end{array}$ & $\begin{array}{l}136 \\
128\end{array}$ & $\begin{array}{c}9 \\
13\end{array}$ & $7 / 38$ & $\begin{array}{l}25 \\
24\end{array}$ & $\begin{array}{l}66 \\
66\end{array}$ & $7 / 10$ \\
\hline & $\begin{array}{c}\text { ALC } \\
\text { Halcones }\end{array}$ & $\begin{array}{c}\text { Bd: } 345 ; 10 / \\
\text { f. II - III }\end{array}$ & 26 & $\begin{array}{l}J \\
D\end{array}$ & $\begin{array}{l}204 \\
209\end{array}$ & $\begin{array}{l}5 \\
7\end{array}$ & $8 / 44$ & $\begin{array}{l}76 \\
73\end{array}$ & $\begin{array}{l}83 \\
81\end{array}$ & $7 / 18$ \\
\hline & $\begin{array}{c}\text { PRES } \\
\text { Presa Potosí }\end{array}$ & $\begin{array}{c}\text { Bd: } 330: 30 / \\
\text { f. II }\end{array}$ & 27 & $\begin{array}{l}\text { J } \\
\text { D }\end{array}$ & $\begin{array}{l}310 \\
321\end{array}$ & $\begin{array}{l}16 \\
11\end{array}$ & $5 / 31$ & $\begin{array}{c}101 \\
90\end{array}$ & $\begin{array}{l}72 \\
72\end{array}$ & $4 / 17$ \\
\hline & $\begin{array}{c}\text { LM } \\
\text { La Maroma }\end{array}$ & $\begin{array}{c}\text { Bd: } 345 ; 16 \text { I } \\
\text { f. II }\end{array}$ & 26 & $\begin{array}{l}\text { J } \\
\text { D }\end{array}$ & $\begin{array}{l}210 \\
194\end{array}$ & $\begin{array}{l}0 \\
6\end{array}$ & $6 / 38$ & $\begin{array}{l}307 \\
304\end{array}$ & $\begin{array}{l}86 \\
88\end{array}$ & $4 / 10$ \\
\hline & $\begin{array}{c}\text { LTC } \\
\text { Cantera type loc. }\end{array}$ & $\begin{array}{c}\text { Bd: } 310: 15 \text { / } \\
\text { f. I - II }\end{array}$ & 9 & $\begin{array}{l}\text { J } \\
\text { D }\end{array}$ & $\begin{array}{l}216 \\
222\end{array}$ & $\begin{array}{l}14 \\
17 \\
\end{array}$ & $19 / 31$ & $\begin{array}{l}93 \\
89\end{array}$ & $\begin{array}{l}66 \\
63\end{array}$ & 9/17 \\
\hline & $\begin{array}{c}\text { PN } \\
\text { Pozuelos North }\end{array}$ & $\begin{array}{c}\text { Bd: } 310 ; 30 / \\
\text { f. II }\end{array}$ & 18 & J & $\begin{array}{l}116 \\
103\end{array}$ & $\begin{array}{l}13 \\
12\end{array}$ & $8 / 65$ & $\begin{array}{l}309 \\
308\end{array}$ & $\begin{array}{l}77 \\
75\end{array}$ & $5 / 8$ \\
\hline & $\begin{array}{c}\text { PS } \\
\text { Pozuelos South }\end{array}$ & $\begin{array}{c}\text { Bd: } 310 ; 30 / \\
\text { f. II }\end{array}$ & 24 & $\begin{array}{l}\text { J } \\
\text { D }\end{array}$ & $\begin{array}{l}113 \\
115 \\
\end{array}$ & $\begin{array}{c}8 \\
10 \\
\end{array}$ & 8/17 & $\begin{array}{l}312 \\
318\end{array}$ & $\begin{array}{l}81 \\
82\end{array}$ & 8/9 \\
\hline \multirow{4}{*}{$\begin{array}{l}\text { 윽 } \\
\text { 인 } \\
\text { 先 } \\
\text { ய }\end{array}$} & $\begin{array}{c}\text { AGU } \\
\text { El Aguaje }\end{array}$ & $\begin{array}{l}\text { Bd: } 320 ; 15 \text { I } \\
\text { f. III }\end{array}$ & 7 & $\begin{array}{l}J \\
\text { D }\end{array}$ & $\begin{array}{c}331 \\
\ldots .\end{array}$ & $\begin{array}{l}0 \\
. .\end{array}$ & $2 / 48$ & $\begin{array}{l}62 \\
60\end{array}$ & $\begin{array}{l}84 \\
86\end{array}$ & $2 / 5$ \\
\hline & $\begin{array}{c}\text { CE } \\
\text { Cerritos }\end{array}$ & $\begin{array}{l}\text { Bd: } 300: 35 / \\
\text { f. III }\end{array}$ & 26 & $\begin{array}{l}\text { J } \\
\text { D }\end{array}$ & $\begin{array}{l}257 \\
260\end{array}$ & $\begin{array}{l}21 \\
20\end{array}$ & $6 / 25$ & $\begin{array}{l}69 \\
67\end{array}$ & $\begin{array}{l}69 \\
68\end{array}$ & $5 / 8$ \\
\hline & $\begin{array}{c}\text { LAR } \\
\text { Los Arroyos }\end{array}$ & $\begin{array}{c}\text { Bd: } 320 ; 15 / \\
\text { f. II - III }\end{array}$ & 14 & $\begin{array}{l}\text { J } \\
\text { D }\end{array}$ & $\begin{array}{l}30 \\
39\end{array}$ & $\begin{array}{l}8 \\
3\end{array}$ & $12 / 43$ & $\begin{array}{l}194 \\
230\end{array}$ & $\begin{array}{l}82 \\
80\end{array}$ & $13 / 15$ \\
\hline & $\begin{array}{c}\text { IC } \\
\text { Ig. Calderón }\end{array}$ & $\begin{array}{c}\text { Bd: } 340: 20 / \\
\text { f. III }\end{array}$ & 24 & $\begin{array}{l}\text { J } \\
\text { D }\end{array}$ & $\begin{array}{l}6 \\
5 \\
\end{array}$ & $\begin{array}{l}15 \\
16 \\
\end{array}$ & $2 / 28$ & $\begin{array}{l}138 \\
138 \\
\end{array}$ & $\begin{array}{l}69 \\
70 \\
\end{array}$ & $2 / 3$ \\
\hline \multirow{4}{*}{$\begin{array}{l}\text { 을 } \\
\text { 인 } \\
\text { 出 } \\
\text { ¿ }\end{array}$} & $\begin{array}{c}\text { MM } \\
\text { Mesa Morenos }\end{array}$ & $\begin{array}{c}\text { Bd: } 280: 30 / \\
\text { f. I }\end{array}$ & 21 & $\begin{array}{l}J \\
\text { D }\end{array}$ & $\begin{array}{l}252 \\
288 \\
\end{array}$ & $\begin{array}{c}11 \\
1 \\
\end{array}$ & $10 / 63$ & $\begin{array}{l}37 \\
45 \\
\end{array}$ & $\begin{array}{l}76 \\
76 \\
\end{array}$ & $8 / 16$ \\
\hline & $\begin{array}{c}\text { LL9 } \\
\text { La Laguna } \\
\end{array}$ & $\begin{array}{l}\text { Bd: } 0,0 \text { I } \\
\text { f. II }-I^{*}\end{array}$ & 26 & $\begin{array}{l}J \\
D\end{array}$ & $\begin{array}{l}293 \\
287 \\
\end{array}$ & $\begin{array}{c}14 \\
9 \\
\end{array}$ & $25 / 40$ & $\begin{array}{l}121 \\
127 \\
\end{array}$ & $\begin{array}{l}76 \\
63 \\
\end{array}$ & $23 / 51$ \\
\hline & $\begin{array}{c}\text { LA10 } \\
\text { Puerta Refugio }\end{array}$ & $\begin{array}{l}\text { Bd: } 0,0 \text { I } \\
\text { f. } 11-1\end{array}$ & 35 & $\begin{array}{l}J \\
\text { D }\end{array}$ & $\begin{array}{l}304 \\
273\end{array}$ & $\begin{array}{l}14 \\
27\end{array}$ & $19 / 55$ & $\begin{array}{c}75 \\
100\end{array}$ & $\begin{array}{l}69 \\
63\end{array}$ & $8 / 31$ \\
\hline & $\begin{array}{c}\text { LALAB } \\
\text { La Laborcilla }\end{array}$ & $\begin{array}{c}\text { Bd: } 340 ; 15 \text { I } \\
\text { f. II }\end{array}$ & 27 & $\begin{array}{l}\text { J } \\
\text { D }\end{array}$ & $\begin{array}{l}326 \\
318\end{array}$ & $\begin{array}{l}15 \\
16 \\
\end{array}$ & $11 / 67$ & $\begin{array}{l}106 \\
110\end{array}$ & $\begin{array}{l}71 \\
73\end{array}$ & 9/13 \\
\hline
\end{tabular}


Major proportions of prolate shapes are found at sites from Western and Eastern groups, whereas most oblate shapes are in the Northern group.

\subsection{Statistical analysis}

Statistical results of each site are shown in Table 2, where sites are listed according to the groups described above. For each site two different types of statistics are shown: (a) the Jelinek statistics (1978, obtained from Anisoft 3 program), showing the means of maximum $\left(k_{1}\right)$ and minimum $\left(k_{3}\right)$ principal susceptibility axes and their corresponding confidence ellipses; and (b) the Gaussian counting point density distribution ( $E=3 *$ Sigma; Robin and Jowett, 1986; obtained from SpheriStat software), which usually shows one maximum density area that almost always corresponds with the $k_{3}$ directions (with only one exception to this that is the LL9 site, the only one with mainly prolated specimens). Density distribution diagrams (Fig. 5) also show 2 to 4 secondary maximum distribution areas, placed $\sim 90^{\circ}$ apart one from another, and along sub-horizontal planes at $30^{\circ}$ to $5^{\circ}$ from the horizontal. These maximum secondary areas usually correspond to $k_{1}$ and $k_{2}$ directions. Values presented in Table 2 of point density distribution statistics corresponding to the $k_{3}$-mean in each site, represent the central point of the area within the higher density distribution curve. The values corresponding to the $k_{1}$-mean are the central point of the area within the maximum secondary areas of density distribution curve which are nearer the $k_{1}$-mean detected by Jelinek statistics. Point density distribution graphs in Fig. 5 also show the plotting of principal axes and their means obtained with Jelinek statistics.

All sites, except LL9, show well-defined magnetic fabrics. The dominant magnetic fabric is characterized by $k_{3}$ axis as the best concentrated one, tending towards a circular distribution according with the following description: (a) In $50 \%$ of sites both minimum ( $\alpha$-min) and maximum ( $\alpha$-max) axes of confidence ellipse present values lower or equal to $10^{\circ}$, the average ratio between values of both axes $(\alpha-\min / \alpha$-max) is 0.6 (a perfect circular distribution would give a ratio of 1 ). (b) In $28 \%$ of sites the $\alpha$-min values are lower than $10^{\circ}$ and the $\alpha$-max are between $10^{\circ}$ and $20^{\circ}$; the average ratio between both values is 0.6 . (c) In $22 \%$ of sites (CL, LAR, LA10 and LL9) the $\alpha$-min values are between $8^{\circ}$ and $23^{\circ}$ and the $\alpha$-max values between $15^{\circ}$ and $51^{\circ}$ showing a clear elliptical to girdle $k_{3}$ distribution (ratio between both values is usually lower than 0.5 ).

On the other hand, $k_{1}$ and $k_{2}$ axes usually have elliptical to girdle distributions along sub-horizontal planes: (a) the $\alpha$-min values are usually lower than $12^{\circ}$ (83\% of cases) or between $19^{\circ}$ and $25^{\circ}$ (17\% of cases); the $\alpha$-min average is $10^{\circ}$. (b) The $\alpha$-max values are usually around $30^{\circ}$ and $40^{\circ}\left(\alpha\right.$-max average $\left.=39^{\circ}\right)$. The average ratio of $\alpha$-min values $/ \alpha$-max values is $=0.3$.

\subsection{Inferred flow directions}

Flow direction was inferred mainly from magnetic foliation imbrication as can be seen in the point density distribution graphs (Fig. 5) where the general geometry of the magnetic fabric can be observed. Inferred flow directions are summarized in Table 3 with annotations of a qualitative estimated error in degrees, dip of foliation and the positionwhen parallel or orthogonal-of $k_{1}$ and $k_{2}$ in relation with
Table 3. Flow inference from the structural corrected AMS data. Inferred flow directions can be graphically seen in Fig. 5. Error of the flow direction is qualitatively estimated (see text); in sites with an $*$ this error was difficult to obtain. The position of $k_{1}$ and $k_{2}$ (= parallel or $\dashv$ orthogonal) in relation with the flow inferred is described; bold $k_{1}$ values mean sites with well developed lineation. Dip of magnetic foliation is given according to $k_{3}$ mean and $k_{1}-k_{2}$ axis distribution. In some sites two opposite inferred flow directions are given because no sense of flow can be inferred. Site with a second direction in parenthesis is an alternate possible inference.

\begin{tabular}{|c|c|c|c|c|c|c|c|}
\hline \multirow{3}{*}{ Group } & \multirow{3}{*}{ Site } & \multirow{3}{*}{$\mathrm{n}$} & \multicolumn{5}{|c|}{$\begin{array}{l}\text { Inferred flow directions } \\
\text { and related data }\end{array}$} \\
\hline & & & \multirow{2}{*}{$\begin{array}{l}\text { Inferred } \\
\text { Flow Dir }\end{array}$} & \multirow{2}{*}{$\begin{array}{c}\text { Error } \\
+/-\end{array}$} & \multicolumn{2}{|c|}{$\begin{array}{c}\text { k1 \& k2 } \\
\text { alignment }\end{array}$} & \multirow{2}{*}{$\begin{array}{l}\text { Dip of } \\
\text { Foliation }\end{array}$} \\
\hline & & & & & $=$ & -1 & \\
\hline \multirow{10}{*}{ 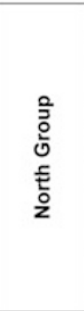 } & PSJ & 21 & 190 & 21 & k1 & $\mathrm{k} 2$ & 18 \\
\hline & LC & 9 & 357 & 27 & k1 & k2 & 5 \\
\hline & $\mathrm{CL}$ & 23 & 110 & $15^{\circ}$ & k2 & k1 & 10 \\
\hline & ESC & 9 & 25 & 16 & k2 & k1 & 23 \\
\hline & ALC & 26 & 80 & $12^{*}$ & $x$ & $x$ & 7 \\
\hline & PRES & 27 & 98 & 20 & $x$ & $x$ & 20 \\
\hline & LM & 26 & $310-130 ?$ & $?$ & $x$ & $x$ & $\leq 5$ \\
\hline & LTC & 9 & 110 & 25 & $x$ & $x$ & 30 \\
\hline & PN & 18 & 300 & 17 & k1 & k2 & 13 \\
\hline & PS & 24 & 316 & $20^{\circ}$ & k1 & k2 & 25 \\
\hline \multirow{4}{*}{$\begin{array}{l}\text { 으 } \\
\text { i⿱ } \\
\text { w }\end{array}$} & AGU & 7 & 60 & 17 & k2 & k1 & 5 \\
\hline & $\mathrm{CE}$ & 26 & 67 & 15 & k1 & k2 & 21 \\
\hline & LAR & 14 & $230(160)$ & $\cdot$ & k1 (k2) & k2 & 10 \\
\hline & IC & 24 & 140 & 8 & $x$ & $x$ & 23 \\
\hline \multirow{4}{*}{ 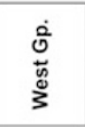 } & MM & 21 & 42 & 45 & $x$ & $x$ & 16 \\
\hline & LL9 & 26 & $20-200$ & $20^{\circ}$ & k2 & k1 & $x$ \\
\hline & LA10 & 35 & 100 & 40 & k1 & $\mathrm{k} 2$ & 24 \\
\hline & LALAB & 27 & 108 & 27 & k1 & k2 & 19 \\
\hline
\end{tabular}

the inferred flow. In most cases the imbrication of magnetic foliation is clearly observed: magnetic foliation is present at 5 to 30 degrees from horizontal plane, but sometimes, mainly in the case of the lower dipping foliation planes, the imbrication is not so clearly defined (as in the LM site). Hence flow directions are not inferred in these sites. In order to estimate the errors of the azimuths of the inferred flow directions, an option is to consider values of $k_{3}$ confidence ellipses projected from the center of the stereodiagram to the horizontal plane. Difficulties for estimating the error with this option come when $k_{3}$ confidence ellipse is over and around vertical positions. A graphical and hence qualitative estimate, considering also the distribution of the other axes (as observed in density distribution curves), was here performed in order to select an angular value for determining the possible error in the inference of flow directions. For similar shape of confidence ellipses (or maximum distribution circles), the more close to the central part of the stereodiagram they are, the higher the error values (as in LM site).

The site with the least organized fabric (LL9) shows a different magnetic fabric pattern, in which the $k_{1}$-mean is slightly more concentrated than the $k_{3}$ mean and prolate anisotropy shapes are dominant. Here the $k_{3}$ axes lie mostly around a sub-vertical plane and $k_{1}$ mean is near to the pole of this sub-vertical plane, suggesting that the $k_{1}$ (longest) axes were rolling in perpendicular positions in relation to the flow. Hence, in this site, a flow direction can be obtained but it does not determine the sense of flow (as in the other cases), since no foliation neither imbrication can be ob- 


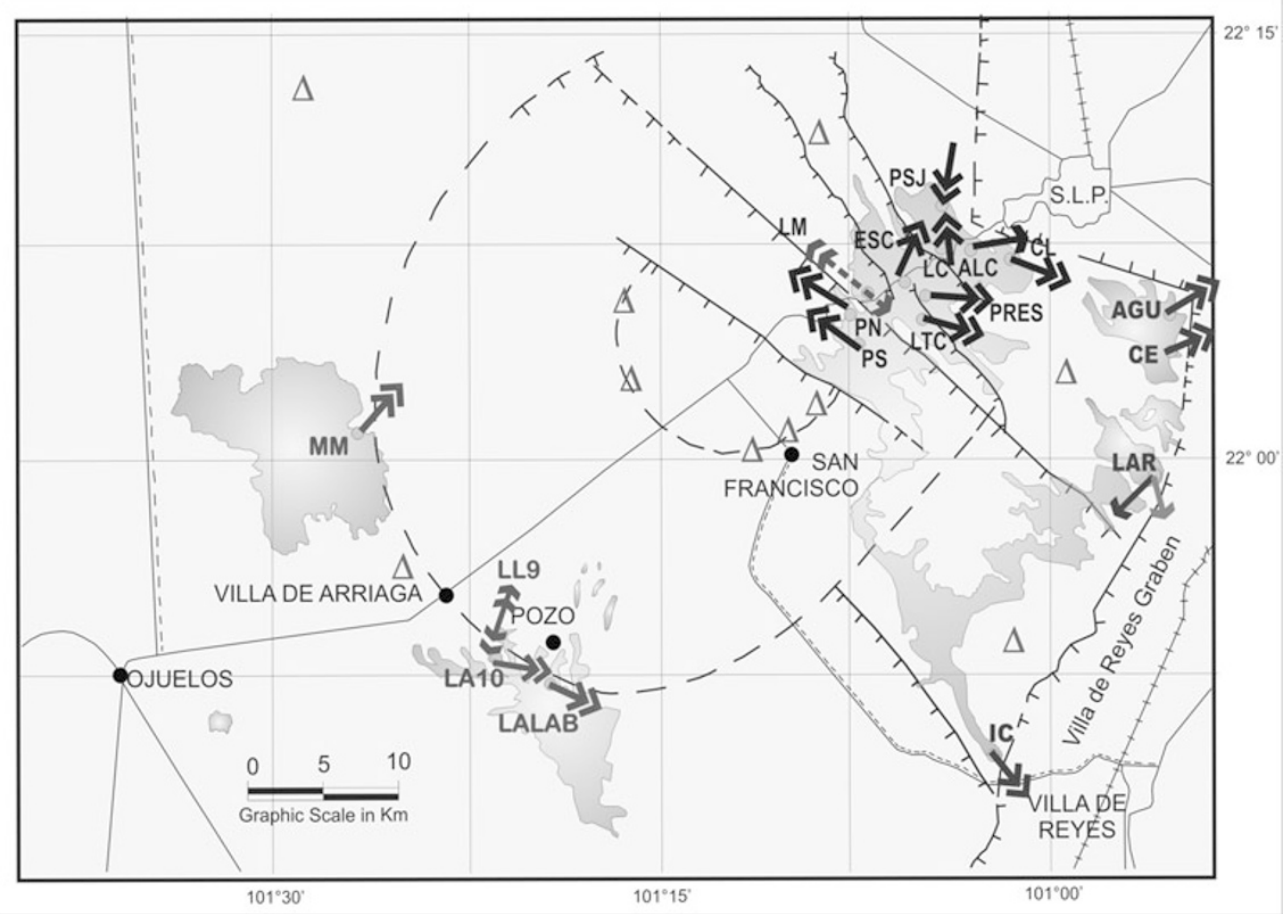

Fig. 6. Flow directions inferred from AMS data on simplified geological-structural map. The $\Delta$ symbol shows the position of older domes as in Fig. 3 .

served. The LAR site which also has an important proportion of prolate specimens (36\%, averaging $T=-0.628)$, presents a type of fabric between the LL9 fabric ( $k_{3}$ with an elongate distribution) and the general fabric described at first ( $k_{3}$ axis with almost circular distributions). The flow direction inferred in this site based on $k_{3}$ mean is $230^{\circ}$, alternatively it may be $160^{\circ}$ according to the orientation of the plane that defines the elongated distribution of the $k_{3}$ axes. Another site with significant number of prolate specimens, the LA10 (34\% prolate, averaging $T=-0.302$ ), also presents $k_{3}$ axes with an elongated distribution, but with the magnetic foliation imbrication clearly defined, a feature that supports the inference of flow direction. There are other sites that present slightly elongated $k_{3}$ distributions but they are mostly oblate and with well defined imbrication planes (CL, MM, LTC).

Comparison of flow direction inferences based on nonstructural and structural corrected data indicates that very different interpretations about the source flow can be obtained from each set. Inferences from the structural corrected set (Fig. 6) indicate flow sources that are more in accordance with other geological indicators-such as facies distribution and position of caldera structure - than those flow sources inferred from the non structural corrected set.

\section{Discussion of AMS Results and Inferred Flow Directions}

The predominant oblate shape present in the Northern group suggest that within these sites the magnetic fabric is mainly a result of low shear component during the flow process, tending to a more fluid flow probably. This seems to be in accordance with the expected kind of flow that corresponds to the dominant intermediate facies of these sites. On the other side, the prolate shapes of the Western and the
Eastern Groups may suggest a more important shear component during the flow; probably a more viscous flow or a flow partially stopped by a physical barrier. This coincides with the structural location of these sites around the caldera rim (West group), or with the dominant distal facies probably near the flow border or near a paleo-topography barrier (East group). Alternatively a particular magnetic mineralogy that have not been detected until now could have produced the differences in the oblate and prolate shapes found in the different groups.

Northern group. The average of flow inference directions obtained from the non corrected data set, points towards the SW, which is opposed to the expected direction considering the position of the caldera structure which should have been a topographic height. Meanwhile, the flow inference directions average obtained from the structural corrected data set, points mainly towards the NE (with several exceptions; Fig. 6), which broadly agrees with the expected direction considering the position of the caldera structure. Exceptions to this appear from sites that lie on a structural block between El Potosino and San Jose Faults, where the flow is parallel to the faults and facing towards the NW in places near the older San Miguelito rhyolite where there should have been a local tongue-shaped paleogeography (see geometry of outcrops in Fig. 3). In addition near these sites some pyroclastic dikes aligned parallel to the faulting and related to the Cantera Ignimbrite are present as well as other younger pyroclastic dikes (from Panalillo Ignimbrite, Torres-Hernández et al., 2006). Another exception to the general NE flow direction inferred is the PSJ site (extreme NE side) with a south flow direction probably due to the influence of the big dome located to the N-NW that should have stopped the flow or simply due to its position very near the border of the ignimbrite flow (Figs. 3 and 6). Despite the 
general flow direction inferred towards NE, flow directions do not seem to point out a central source origin. Instead, linear source areas are suggested; one of them might correspond to El Potosino Fault and/or to the nearest fault to the north for ESC, LTC and PRES sites. LTC proximal facies with co-ignimbrites suggest that this site is beside or very near to its source. The same source area or alternatively another linear source area corresponding to a northward fault seems to be the origin of the flow for LC, ALC, CL and probably PSJ sites.

Western group. All sites from this group are located along the caldera border. Massive facies in 2 of the 4 sites of this group did not allow performing any structural correction. Magnetic fabrics of these sites have important contributions of prolate shapes, probably due to the influence of the caldera rim which should have acted as a barrier and produced additional shear during the flow processes. The site within the caldera (LL9) do not present any magnetic foliation at all; instead, their $k_{3}$ axes lie along a vertical plane (perpendicular to the caldera rim), and presents a relatively more developed lineation (parallel to the caldera rim). Our interpretation to this is a flow direction perpendicular to the caldera rim, flow in which the $k_{1}$ axes were rolling as in a turbulent flow probably because the rim acted as a barrier (Figs. 5(B) and 6). The site outside the caldera (LA10) shows somewhat similar magnetic axes distribution with a relatively well-defined lineation also parallel to the caldera rim and $k_{3}$ axis with an elliptical distribution but still defining a foliation dipping to the SW, direction that is considered as the flow direction. At the other 2 sites the flow inference direction points to the NW, to the inside of the caldera, and to the SW, parallel the caldera rim, as in the LA10 site. The conclusion of this group is that the caldera rim was the linear source area of the flow for all these sites.

Eastern group. The average of flow inference directions obtained from structural corrected data points away from the height that formed the caldera structure: to NE and SE (here we are considering the alternate inference direction of the LAR site). As in the Northern Group, the source of flow is more likely to be linear than have originated from central areas, corresponding to fractures where later normal faults were been developed. AGU and CE sites should both have the same linear source area corresponding to faults located at the south of their location. For the LAR site, the source area was probably the same than AGU and CE or alternatively another linear source located in a southern position of this site (the Potosino Fault continuation?). The flow direction inferred from magnetic fabric and the presence of significant prolate shapes may be related with the older dome located at the NW that should act as a paleogeographic barrier. In the IC site, flow direction inferred from magnetic fabric and observed distal facies suggest that flow might have come from the caldera rim. The IC higher $P_{\mathrm{j}}$ values do not seem to be related to any flow dynamics or emplacement features in particular but to its mineralogy rich in tiny hornblende crystals, partially altered to hematite as can be seen in microscopic studies. The abundance of hematite probably influenced the dominant oblate shapes of this site.

\section{Conclusions}

Inferred flow directions analysis from AMS data sets, with structural correction and without structural correction, indicates that the first data set is the one that best agrees with the expected overall direction, considering paleogeographic elements, such as the rhyolitic domes of the previously formed San Miguelito Rhyolite and the proper positioning of the caldera structure whose external border should have had a relative higher topography.

The flow directions inferred from AMS analysis, considering the facies distribution, of the sites from the Northern Group and the three northern sites from de Eastern Group, indicate several linear sources located in different positions along the El Potosino Fault or parallel fractures near to it. The other sources inferred in this work are along the rim of the caldera structure.

The caldera structure described as related to the Cantera Ignimbrite is also related to the older and younger rhyolitic and ignimbritic units (from San Miguelito Rhyolite to Upper Panalillo ignimbrite and even some younger Miocene units not shown in Fig. 3, detailed description in TorresHernández, 2008). The geometry of this caldera, according to its associated volcanic outcrops, the NW-SE faultingfracture system present in the eastern side, as well as the AMS results presented here, suggest a caldera shape similar to that of the trapdoor type caldera of Lipman (1997), which was described as related to an asymmetrical pluton. In this case the magmatic chamber was apparently emplaced in a previously NW-SE faulting-fracture system as can be assumed from the distribution of the Cretaceous basement. In this structure some volcanic flows rose up from the caldera structure meanwhile the rest came from the NW-SE fracture system, along which later developed faults downthrown to the SW, a geometry that may be related with the collapse of the magmatic chamber. The first or main trapdoor fracture could have been located where the San Jose Fault is now, later shifting near and parallel to the El Potosino fault. Further detailed field studies are needed to constrain more this proposal or modify it according to any new findings.

Acknowledgments. We greatly appreciate the financial support to LAV through the CONACYT research Project 42682. We thank to Guillermo Labarthe for his unconditional support to RTH throughout his PhD studies and for sharing with everyone his expertise and knowledge in this area. Special thanks to Antonio Gonzalez Rangel for the AMS measurements and to Ana Maria Soler for her help in solving some laboratory problems during the evolution of this work. Last but not least we also thank Jerome Bascou and to an anonymous reviewer who greatly helped to improve this work.

\section{References}

Aguirre-Díaz, G. J. and G. Labarthe-Hernández, Fissure ignimbrites: Fissure-source origin for voluminous ignimbrites of the Sierra Madre Occidental and its relationship with Basin and Range faulting, Geology, 31, 773-776, 2003.

Alva-Valdivia, L. M., J. Rosas-E., T. Bravo-M., J. Urrutia-F., B. Henry, C. Caballero, M. L. Rivas-S, A. Goguitchaichvili, and H. López, Paleomagnetic and magnetic fabric studies of the San Gaspar ignimbrite, western Mexico-constraints on emplacement mode and source vents, J. Volcanol. Geotherm. Res., 147, 68-80, 2005.

Cagnoli, B. and D. H. Tarling, The reliability of anisotropy of magnetic susceptibility (AMS) data as flow direction indicators in friable base surge and ignimbrite deposits: Italian examples, J. Volcanol. Geotherm. 
Res., 75, 309-320, 1996.

Ekren, E. B. and F. M. Byers, Ash-flow fissure vent in west-central Nevada, Geology, 4, 247-251, 1976.

Ekren, E. B., D. H. McIntyre, and E. H. Bennett, High-temperature, largevolume, lava-like ash flow tuffs without calderas in southwestern Idaho, Geol. Surv. Prof. Paper, 1272, 76 pp., 1983.

Ellwood, B. B., Estimates of flow direction for calc-alkaline welded tuffs and palaeomagnetic data reliability from anisotropy of magnetic susceptibility measurements: central San Juan Mountains, south-west Colorado, Earth Planet. Sci. Lett., 59, 303-314, 1982.

Elston, W. E. and E. I. Smith, Determination of flow direction of rhyolite ash flow tuffs from fluidal textures, Geol. Soc. Am. Bull., 81, 3393-3406, 1970.

Hillhouse, J. W. and R. E. Wells, Magnetic fabric, flow directions, and source area of the lower Miocene Peach Springs Tuff in Arizona, California, and Nevada, J. Geophys. Res., 96(B7), 12443-12460, 1991.

Incoronato, A., F. T. Addison, D. H. Tarling, G. Nardi, and T. Pescatore, Magnetic fabric investigations of pyroclastic deposits from Phlegrean Fields, southern Italy, Nature, 306, 461-463, 1983.

Jelinek, V., Statistical processing of anisotropy of magnetic susceptibility measured on groups of specimens, Studia Geoph. Geod., 22, 50-62, 1978.

Jelinek, V., Characterization of the magnetic fabrics of rocks, Tectonophysics, 79, 63-67, 1981

Knight, M. D., G. P. L. Walker, B. B. Ellwood, and J. F. Diehl, Stratigraphy, paleomagnetism, and magnetic fabric of the Toba Tufts: constraints on the sources and eruptive styles, J. Geophys. Res., 91, 10355-10382, 1986.

Labarthe-Hernández, G. and M. Tristán-González, Cartografía geológica de la Hoja San Luis Potosí, Universidad Autónoma de San Luis Potosí, Instituto de Geología y Metalurgia: Folleto Técnico, 59, 41 pp., 1 map, 1978.

Labarthe-Hernández, G. and L. S. Jiménez-López, Características físicas de lavas e ignimbritas riolíticas en la Sierra de San Miguelito, S.L.P., Universidad Autónoma de San Luis Potosí, Instituto de Geología: Folleto Técnico, 114, 31 pp., 1 map, 1992.

Labarthe-Hernández, G. and L. S. Jiménez-López, Geología del Domo Cerro Grande, Sierra de San Miguelito, S.L.P., Universidad Autónoma de San Luis Potosí: Instituto de Geología y Metalurgia: Folleto Técnico, 117, 22 pp., 1 map, 1993.

Labarthe-Hernández, G. and L. S. Jiménez-López, Geología de la porción sureste de la Sierra de San Miguelito, S.L.P., Universidad Autónoma de San Luis Potosí, Instituto de Geología: Folleto Técnico, 120, 34 pp., 1 map, 1994.

Labarthe-Hernández, G., M. Tristán-González, and J. J. Aranda-Gomez, Revisión estratigráfica del Cenozoico de la parte central del Estado de San Luis Potosí, Universidad Autónoma de San Luis Potosí, Instituto de Geología y Metalurgia: Folleto Técnico, 85, 208 pp., 1982.
Labarthe-Hernández, G, L. S. Jiménez-López, and J. J. Aranda-Gomez, Reinterpretación de la geología del Centro Volcánico de Ahualulco, SLP, Universidad Autónoma de San Luis Potosí, Instituto de Geología: Folleto Técnico, 121, 30 pp., 1995.

Lipman, P. W., Subsidence of ash-flow calderas: relation to caldera size and magma chamber geometry, Bull. Volcanol., 59, 198-212, 1997.

MacDonald, W. D. and H. C. Palmer, Flow directions in ash flow tuffs: a comparison of geological and magnetic susceptibility measurements, Tshirege member (upper Bandelier Tuff), Valles caldera New Mexico, USA, Bull. Volcanol., 53, 45-59, 1990.

Ort, M., M. Rosi, and C. D. Anderson, Correlation of deposits and vent locations of the proximal Campanian Ignimbrite deposits, Campi Flegrei, Italy, based on natural remanent magnetization and anisotropy of magnetic susceptibility characteristics, J. Volcanol. Geotherm. Res., 91 167-178, 1999.

Ort, M. H., G. Orsi, L. Pappalardo, and R. V. Fisher, Anisotropy of magnetic susceptibility studies of depositional processes in the Campanian Ignimbrite, Italy, Bull. Volcanol., 65, 55-72, 2003.

Palmer, H. C. and W. D. MacDonald, Anisotropy of magnetic susceptibility in relation to source vents of ignimbrites: empirical observations, Tectonophysics, 307, 207-218, 1999.

Rhodes, R. C. and E. I. Smith, Distribution and directional fabric of ashflow sheets in the north-western Mogollon Plateau, New Mexico, Geol. Soc. Am. Bull., 83, 1863-1869, 1972.

Robin, P.-Y. F. and E. C. Jowett, Computerized density contouring and statistical evaluation of orientation data using counting circles and continuous weighting functions, Tectonophysics, 121, 207-223, 1986.

Suzuki, K. and T. Ui, Grain orientation and depositional ramps as flow direction indicators of a large-scale pyroclastic flow deposit in Japan, Geology, 10, 429-433, 1982.

Torres-Hernández, R., Las fuentes de las Ignimbritas Cantera y Panalillo en el Campo Volcánico de San Luis Potosí-, S.L.P., Universidad Autónoma de San Luis Potosí, PhD Thesis, 2008 (unpublished).

Torres-Hernández, R., G. Labarthe-Hernández, A. Aguillón-Robles, Gómez-Martín Anguiano, and J. L. Mata-Segura, The pyroclastic dikes of the Tertiary San Luis Potosí volcanic field: Implications on the emplacement of Panalillo ignimbrite, Geofísica Internacional, 45(4), 243 253, 2006.

Wright, J. V. and G. P. L. Walker, The ignimbrite source problem: the significance of a co-ignimbrite lag-fall deposit, Geology, 5, 729-732, 1977.

C. I. Caballero-Miranda (e-mail: cecilia@geofisica.unam.mx), J. R. Torres-Hernández, and L. M. Alva-Valdivia 